Article

\title{
Dimensionless Analysis for Investigating the Quality Characteristics of Aluminium Matrix Composites Prepared through Fused Deposition Modelling Assisted Investment Casting
}

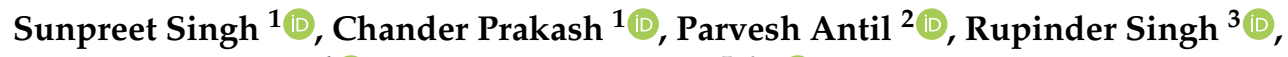 \\ Grzegorz Królczyk 4 (D) and Catalin I. Pruncu ${ }^{5,6, *(D)}$ \\ 1 Department of Mechanical Engineering, Lovely Professional University, Phagwara, Punjab 144411, India; \\ snprt.singh@gmail.com (S.S.); chander.mechengg@gmail.com (C.P.) \\ 2 Department of Basic Engineering, College of Agricultural Engineering and Technology, CCS HAU, Hisar, \\ Haryana 125004, India; parveshantil.pec@gmail.com \\ 3 Manufacturing Research Laboratory, Production Engineering Department, \\ Guru Nanak Dev Engineering College, Ludhiana 141006, India; rupinderkhalsa@gmail.com \\ 4 Faculty of Mechanical Engineering, Opole University of Technology, 76 Proszkowska St., 45-758 Opole, \\ Poland; g.krolczyk@po.opole.pl \\ 5 Mechanical Engineering, Imperial College London, Exhibition Rd., London SW7 2AZ, UK \\ 6 Mechanical Engineering, School of Engineering, University of Birmingham, Birmingham B15 2TT, UK \\ * Correspondence: c.pruncu@imperial.ac.uk
}

Received: 16 May 2019; Accepted: 11 June 2019; Published: 13 June 2019

check for

\begin{abstract}
The aluminium matrix composites (AMCs) have become a tough competitor for various categories of metallic alloys, especially ferrous materials, owing to their tremendous servicing in the diversified application. In this work, additional efforts have been made to formulate a mathematical model, by using dimensionless analysis, able to predict the mechanical characteristics of the AMCs that have already been optimized and characterized by the authors. Here, the experimental and statistical data obtained from the Taguchi L18 orthogonal array and analysis of variance (ANOVA) have been used. They permit collection of the output responses and allow the identification of significant process parameters, respectively, which thereafter were used to design the mathematical model. Second order polynomial equations have been obtained from the specific output response and the relevant input parameter were incorporated with the highest level of contribution. The obtained quadratic equations indicate the regression values $\left(\mathrm{R}^{2}\right)$ equal to unity, hence, proving the performances of the fit. The results demonstrate that the developed mathematical models present very high accuracy for predicting the output responses.
\end{abstract}

Keywords: fused deposition modelling; investment casting; mathematical modelling; aluminium matrix composite

\section{Introduction}

In the last two decades, the rapid advancement of technology has contributed to large modification in the manufacturing sector. During this period, the demand for materials that can sustain the extreme level of service conditions increased globally. Specifically, in aerospace and automobile sectors, the requirement of materials having high strength, toughness, hardness, and prolonged service life was always a challenge. Apart from these properties, one of the major requirements is 'light weight'. Different studies have reported the needs of lighter material as one of the motivations behind the invention of reinforced materials, commonly, referred to as metal matrix composites [1-3]. 
Amongst various categories of metal matric composites, the one based on the aluminium $(\mathrm{Al})$ matrix is in high demand, owing to its excellent thermal, mechanical, tribological, chemical, and structural characteristics [4-6]. Further, there exists a wide range of manufacturing processes, which can be used for the fabrication of the tailor-made composites with desirable properties [7]. Specifically, aluminium matrix composites (AMCs) are basically popular because of the low weight/density ratio, high wear resistance, cost effectiveness, high elastic modulus, and excellent strength [8-11]. Further, Sajjadi et al. reveal $\mathrm{Al}-\mathrm{Al}_{2} \mathrm{O}_{3}$ as the most popular type of $\mathrm{AMC}$ s because it contains micro $\mathrm{Al}_{2} \mathrm{O}_{3}$ particles within the matrix of $\mathrm{Al}$ [12]. Such as, the $\mathrm{Al}-\mathrm{Al}_{2} \mathrm{O}_{3}$ based composites have continually extended their applicability within industrial applications $[13,14]$.

Traditionally, the reinforcements are introduced to the metallic matrix via an ex-situ method $[15,16]$, wherein the matrix and reinforcements are mixed with each other outside the mould cavity or die. This method of reinforcement results in poor wettability between the reinforcement and the matrix due to the increased surface area and presence of surface contamination on the reinforcements [17]. In order to overcome the interface issue, recent trends have been shifted towards the use of reinforcements within the cavity or mould itself [18]. As defined in the literature, there are various routes, commercially available, for the preparation of AMC. The most widely used commercial routes are the stir casting and powder metallurgy [19-21]. There, the machinability of AMCs is very poor, in contrast to pure $\mathrm{Al}$, due to the brittle reinforcements in the matrix. The investment casting (IC) process has shown its superiority, over the other solutions; in-terms of producing highly complex and near-net shaped parts with very fine surface finish [22]. Additionally, this process is simple, cost effective, and allows manufacturing a wide range of materials; however, the stretched production cycles represents one of the critical challenges for the IC [23,24]. As continuum improvement, the hybridization of IC and stir casting process has become the most popular methods to develop superior metal matrix composites (MMCs) $[25,26]$. The intrinsic weaknesses of IC process (such as: low strength of wax pattern, un-economical injection moulding cost, high die design cost, and longer production runs) can be eliminated by using fused deposition modelling (FDM) process for pattern making [27-30]. FDM works on the same principle as the Additive Manufacture (AD), wherein the thin plastic slices are deposited at a defined distance. The interface, therefore, can result in poor surface finish due to an integral stair-casing. Boschetto and Veniali suggested the barrel finishing of formed FDM parts as an efficient method to enhance their surface finish [31].

The collaboration of FDM and IC has been extensively researched in the literature, which duly cited the myriads of merits [32-36]. In the recent years, the authors have investigated a novel method for the production of the in-situ based AMCs, through the use of FDM assisted by the IC process. In this respect, the authors developed in-house composite polymeric composites that were used for the production of sacrificial patterns for the IC process. As observed in $[1,2,37]$, the manufactured $\mathrm{Al}$ castings consist of $\mathrm{Al}_{2} \mathrm{O}_{3}$ distributions, which permit the validation of the authenticity of the adopted methodology. Further, the input process parameters; refer to Appendix A (i.e., Table A1), have been optimized by using Taguchi L18 orthogonal array-based design of experimentation techniques in response of dimensional accuracy [1], surface hardness [2], and surface roughness [3]. In this work, mathematical models, based on the obtained results of [1-3], for all the aforementioned output responses have been developed by using dimensionless modelling, Buckingham's $\pi$-approach. Further, regression equations have been implemented against the best features of the input process parameters, as per analysis of variance (ANOVA).

\section{Materials and Methods}

Figure 1 presents the methodology adopted in this research. By using a Fish bone diagram (see details on Figure 2), we highlight the main process parameters associated to the IC which can affect the quality features of the IC components. The number of IC slurry layer $\left(\mathrm{N}_{\mathrm{SL}}\right)$ has been judicially selected as an input parameter due to its significance highlighted in the literature [38-40]. The following are 
the procedural steps followed to obtain AMCs, which refer to the original Taguchi L18 orthogonal array (Table A1), as given in the Appendix A:

- The alternative feedstock filaments $\left(\mathrm{F}_{\mathrm{P}}\right)$ have been prepared using $\mathrm{PA}, \mathrm{Al}_{2} \mathrm{O}_{3}$, and $\mathrm{Al}$ in different \%wt. proportions with the help of single screw extrusion process.

- The formed filaments were used for the development of sacrificial patterns of cubical shape with three different volumes $\left(\mathrm{V}_{\mathrm{P}}\right)$, such as $17,576 \mathrm{~mm}^{3}, 27,000 \mathrm{~mm}^{3}$, and $39,304 \mathrm{~mm}^{3}$. They were produced at low, high, and solid density of FDM process $\left(D_{P}\right)$ by using uPrint-SE system of Stratasys Inc. (Edina, MN, USA). In the works, reported previously, it has been seen that the change in the in-fill density affects the mechanical and tribological performances of the developed AMCs [1-3]. The prime reason behind the selection of FDM technology is due to its affordability and suitability for hybridization within the IC process $[23,24,41]$. Further, the selection of the process parametric levels from previous studies has been judicially selected, based on the pilot studies.

- Prior to shell moulding, the barrel finishing (BF) process was performed on the samples, for the refurbishment of resulted surface finish [31]. Here, barrel finishing time $\left(\mathrm{BF}_{\mathrm{T}}\right)$ and barrel finishing media weight $\left(\mathrm{BF}_{\mathrm{W}}\right)$ have been selected as input process parameters.

- Then, the IC moulds were prepared by coating the trees (consisting of riser, pouring basin, gating, and also the FDM printed sacrificial pattern) with refractory layers of silica. The number of IC slurry layers $\left(\mathrm{N}_{\mathrm{SL}}\right)$ has also varied in accordance to Table A1 in the Appendix A.

- Autoclaving and baking were performed in one step at $1150{ }^{\circ} \mathrm{C}$ (by maintaining the pouring sprue in a vertical up position so that the $\mathrm{Al}_{2} \mathrm{O}_{3}$ filler particles could be arrested within the cavity only). At this range of temperature, the matrix of the sacrificial patterns evaporates, immediately, without causing mould cracks.

- Finally, pouring of molten Al-6063 has been carried out.

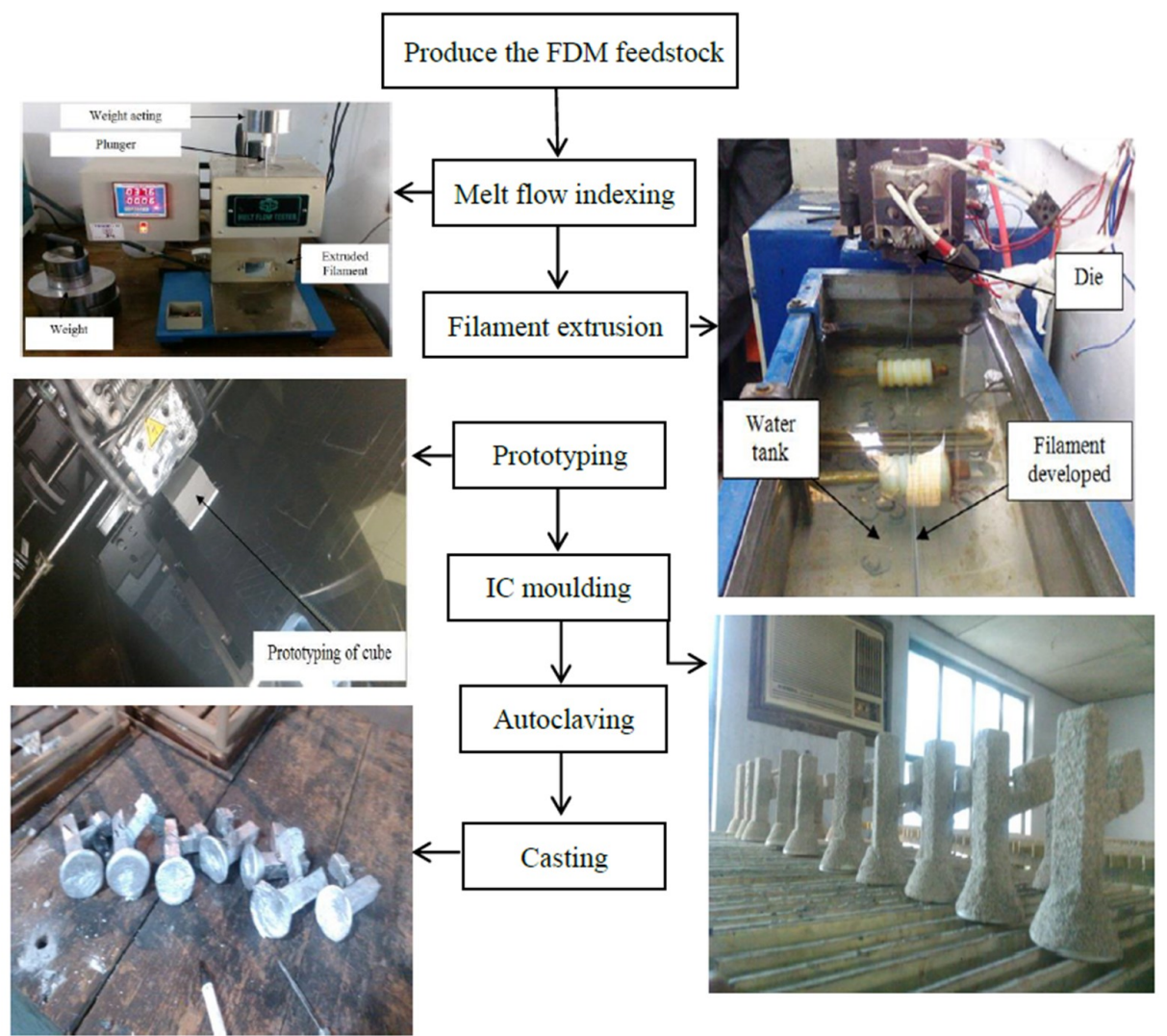

Figure 1. Step by step procedure of aluminium matrix composites (AMC) development. 


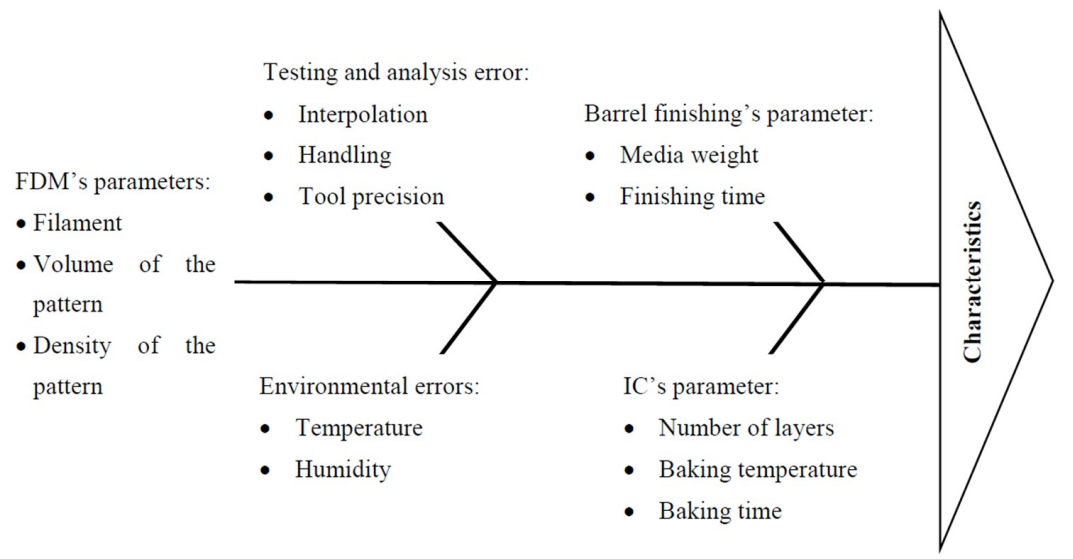

Figure 2. Fish bone diagram for prepared castings.

The castings manufactured were tested for surface hardness, dimensional accuracy and surface roughness by using HVS-1000BVM hardness tester (HV0.01 scale; ASTM-E384, Laizhou, China), Vernier Caliper (Mitutoyo: least count 0.01mm, Takatsu-ku, Kawasaki, Japan) and Mitutoyo SJ-210 (Japan, ISO: 1997) surface roughness tester, respectively. For microstructural evaluation, the Scanning Electron Microscopy (SEM, JEOL, Peabody, MA, USA) analysis has been performed on the casting manufactured in the experiment \#16, \#17 and \#18 associated to Table A1. It has been seen that the $\mathrm{Al}_{2} \mathrm{O}_{3}$ particles presented in $\mathrm{Al}$ matrix allow to enhance the quality characteristics of the castings, especially the hardness on the surface. Figure 3 shows the SEM micrographs and their associated Energy Dispersive Spectroscopy (EDS) spectrums (JEOL, USA). The measurements indicate the presence of $\mathrm{Al}$, $\mathrm{O}, \mathrm{Si}, \mathrm{Fe}$, and C-peaks, which confirm the existence of alumina. These elements identified on the EDS measurements (i.e., $\mathrm{Al}, \mathrm{O}$, and $\mathrm{C}$ ) are the common sign of alumina surface [42]. They were noted as well as the presence of elements $\mathrm{Fe}$ and $\mathrm{Si}$, which denote some small impurity.
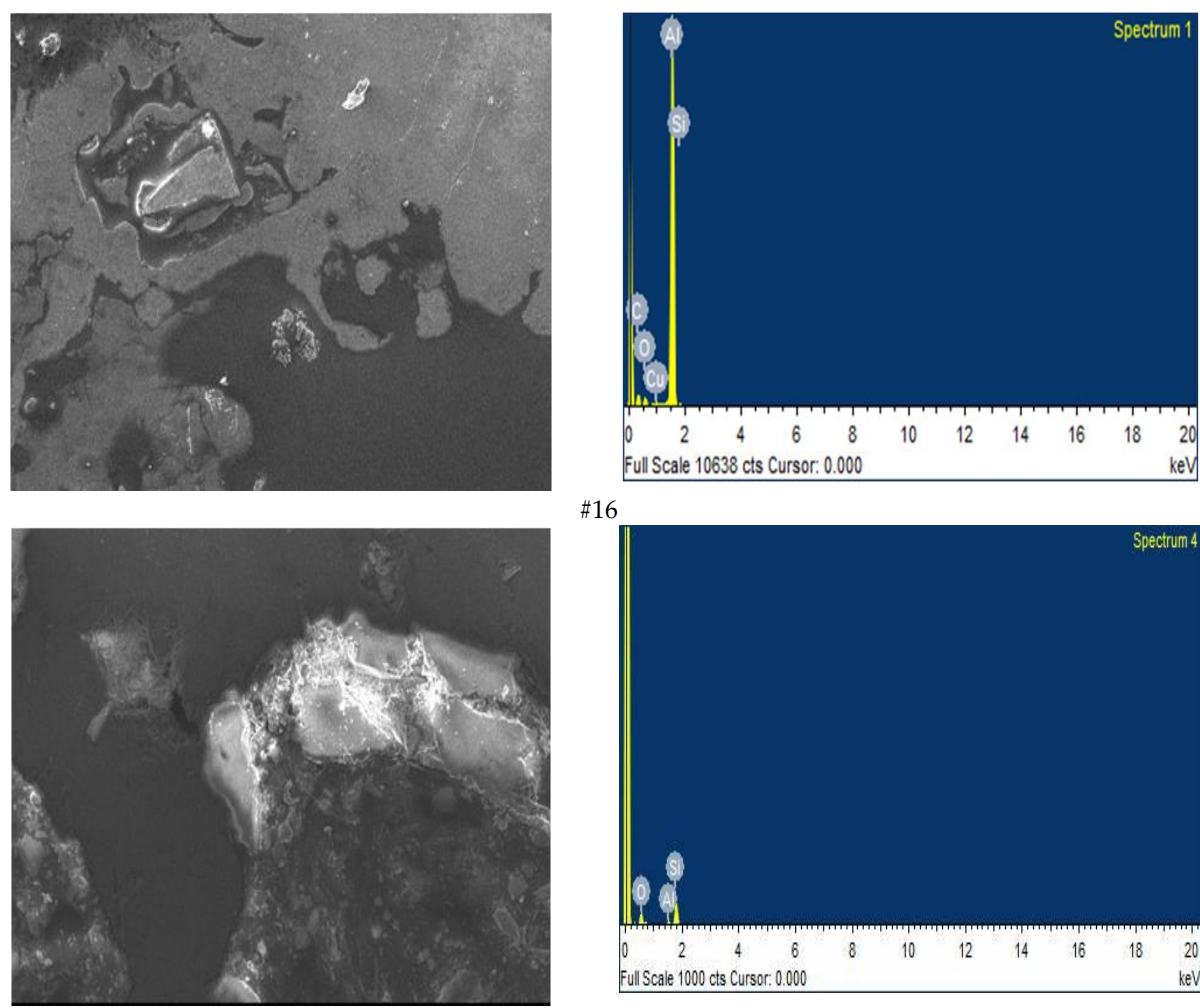
$\# 16$

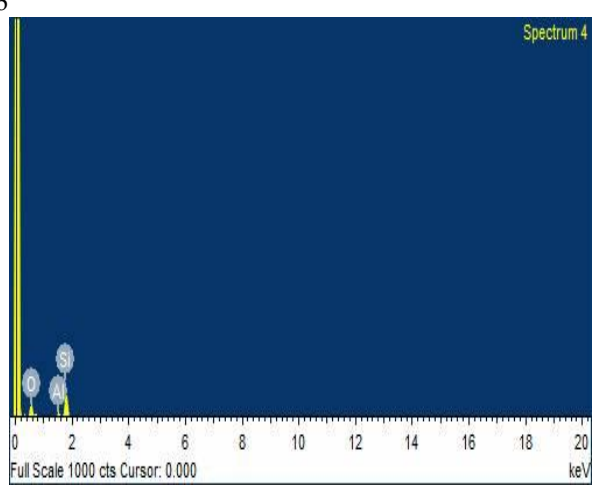

$\# 17$

Figure 3. Cont. 

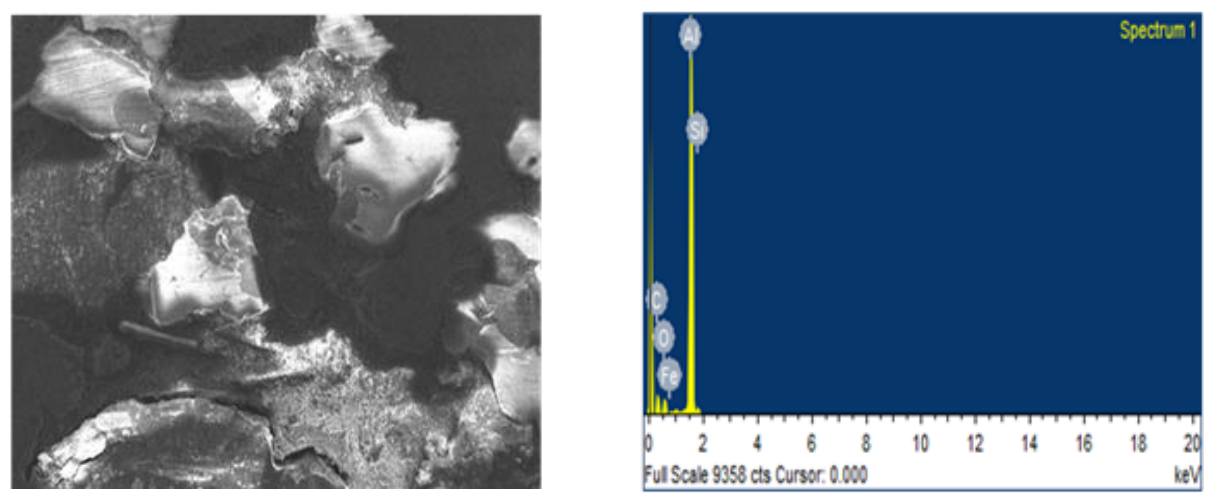

$\# 18$

Figure 3. SEM micrograph and EDS spectrum of experiment \#16, \#17, and \#18.

\section{Dimensionless modelling: Buckingham Pi Approach}

Dimensionless modelling of the experimental data is considered an efficient method in order to formulate analytic mathematical functions that are out of a highly complex experimental system associated to numerous process parameters [43]. The concept of dimensionless analysis helps to reduce the influence of variables by means of physical equations [44-46]. To date, dimensionless modelling with the help of Buckingham Pi approach has been extensively investigated for a wide range of scientific and engineering applications including fluid dynamics [47], energy [48], electronics [49], heat transfer [50] and others. According to the Buckingham approach, any practical problem containing " $\mathrm{n}$ " factor sand further " $\mathrm{m}$ " dimensions, then the subtraction of $\mathrm{n}$ and $\mathrm{m}$ will result the counts of independent factors, which could be assumed. Presently, " $\mathrm{n}$ " and " $\mathrm{m}$ " are 7 and 3, respectively. Therefore, the problem will consist of $\pi 1, \pi 2, \pi 3$ and $\pi 4$ that are the dimensional magnitudes. Furthermore, the mathematical formulae derived for the assumed independent parameters help to develop the dimensional relationships by following a set of standard steps [51,52]. Standard quantities of the same physical nature (mass, length, and time) are used based on fundamental units. Consequently, it can be said that these systems belong to the same class. To generalize, a set of systems of units that differ only in the magnitude (but not in the physical nature) of the fundamental units are called a class of systems of units [53]. Unlike other statistical approaches, the mathematical modelling in the case of Buckingham' Pi approach could be very tedious if a proper set of producers is not considered. Based on [53], following are the step-by-step descriptions of the modelling process adopted in the present work:

i. First of all, the units of the input and the output process parameters have been unified and converted into physical quantities (such as $\mathrm{M}, \mathrm{L}$, and T). Further, it is of utmost importance to highlight that any kind of categorical parameter, either input or output, is not suitable for the modelling. Moreover, upon such conversions, it should be considered that the replacement could be represented in-terms of M, L, and T formats. Therefore, in present work, the original Table A1 in the Appendix A has been modified in order to balance the units, as well as to convert the qualitative parameters into quantitative. For instance, the parameter "filament proportion" has been quantified in-terms of its tensile strength; density of the FDM pattern has been considered in terms of mass and volume; mould wall thickness has been converted from a number of layers to thickness of the wall, etc. Table 1 is the final prepared modified version of Table A1.

The obtained dimensions of input and output parameters would be:

Hardness $(\mathrm{H})$ as $\mathrm{ML}^{-1} \mathrm{~T}^{-2}$, Dimensional accuracy as $\mathrm{L}$,

Surface roughness as $\mathrm{L}$,

Filament proportion $(\mathrm{P})$ in-terms of tensile strength of filament as $\mathrm{MLT}^{-2}$,

Volume of FDM reinforced pattern $(\mathrm{V})$ as $\mathrm{L}^{3}$,

Density of FDM pattern $(\varrho)$ as $\mathrm{ML}^{-3}$,

BF cycle time ( $(t)$ as $T$, 
BF media weight (W) as M and the Number of IC slurry layers (l) resulting into mould wall thickness as L.

ii. Then, it is mandatory to find out the significance level of the input process parameters for the measured outcomes. In the present case, ANOVA has been implemented with the help of MINITAB-17 based statistical software in order to identify the significance and contribution of input parameters. Table 2 shows the contribution percentage of input process parameters for surface hardness, dimensional accuracy, and surface roughness.

iii. Before starting to formulate the $\pi$ equations (let us say ' $x$ '), it is necessary to identify the ' $x-$ $1^{\prime}$ top performing input parameters. For instance, in the case of surface hardness, when ' $x$ ' is equal to 4 that allows to develop $4 \pi$-equations, three top performing input parameters have to be identified.

iv. Now, the top performing input parameters and the output parameters being analyzed represent the $\pi$ equations.

v. After calculating the $\pi$ equations, the $\pi 1$ (related to the output parameter) is solved as a function of other $\pi \mathrm{s}(\pi 2, \pi 3$, and $\pi 4$, consisted of input parameters).

vi. Once the step-v is completed, a constant ' $K$ ' has been considered whose value has been driven from a second order quadratic equation of the fitness curve that connect the output response and the most contributing input parameter.

vii. Further, the fitness curve should be plotted between the measured output values and the corresponding values of the most significant input parameter, while keeping the rest of the parameters constant. Alternatively, in the present case, the plots have been drawn between the three levels of the input process parameters and the average of the corresponding output result. For instance, in case of Figure 4, the average of hardness for experiment \#1, \#4, \#7, \#10, $\# 13$, and \#16 has been plotted against first level of $\mathrm{F}_{\mathrm{D}}\left(5.12 \times 10^{-6} \mathrm{~N} / \mathrm{mm}^{3}\right)$ and the average of hardness for experiment \#2, \#5, \#8, \#11,\#14, and \#17 has been plotted against second level of $\mathrm{F}_{\mathrm{D}}\left(7.63 \times 10^{-6} \mathrm{~N} / \mathrm{mm}^{3}\right)$. Similar procedure has been adopted for the third level of the $\mathrm{F}_{\mathrm{D}}$.

viii. Noticeably, the regression $\left(\mathrm{R}^{2}\right) \sim 1$ indicates the best fitness of the data.

\subsection{Hardness}

In the present study, hardness is considered a function of all input process parameters that is expressed by Equation (1).

So,

$$
H=f(P, V, \varrho, t, W, l)
$$

Based on the Table 2; the least significant parameters for this particular parameter are BF cycle time, BF media filament proportion, and weight that will directly go in " $\pi$ " groups. The " $\pi$ " eqns. for hardness can be written as:

$$
\begin{aligned}
\pi_{1} & =\mathrm{H}(\mathrm{F})^{\mathrm{a} 1}(\mathrm{t})^{\mathrm{b} 1}(\mathrm{~W})^{\mathrm{c} 1} \\
\pi_{2} & =\varrho(\mathrm{F})^{\mathrm{a} 2}(\mathrm{t})^{\mathrm{b} 2}(\mathrm{~W})^{\mathrm{c} 2} \\
\pi_{3} & =1(\mathrm{~F})^{\mathrm{a} 3}(\mathrm{t})^{\mathrm{b} 3}(\mathrm{~W})^{\mathrm{c} 3} \\
\pi_{4} & =\mathrm{V}(\mathrm{F})^{\mathrm{a} 4}(\mathrm{t})^{\mathrm{b} 4}(\mathrm{~W})^{\mathrm{c} 4}
\end{aligned}
$$

After substituting the decided dimensions in the " $\pi$ " groups, Equations (6), (8), (10), and (12) are formed. Now, in order to solve these further, the resulted equations are equated to zero. For instance, the $\pi 1$ will be solved as follows:

$$
\pi_{1}=\mathrm{ML}^{-1} \mathrm{~T}^{-2}\left(\mathrm{ML}^{-1} \mathrm{~T}^{-2}\right)^{\mathrm{a} 1}(\mathrm{~T})^{\mathrm{b} 1}(\mathrm{M})^{\mathrm{c} 1}
$$


Equating the basic dimensions to zero:

$\mathrm{M}: 1+\mathrm{a}_{1}+\mathrm{c}_{1}=0$

L: $-1-\mathrm{a}_{1}=0$

$\mathrm{T}:-2-2 \mathrm{a}_{1}+\mathrm{b}_{1}=0$

We get,

$\mathrm{a}_{1}=-1, \mathrm{~b}_{1}=0$ and $\mathrm{c}_{1}=0$

So, Equation (2) can be re-written as:

$$
\pi_{1}=\mathrm{H} / \mathrm{F}
$$

Similarly, on solving $\pi_{2}$;

$$
\pi_{2}=\mathrm{ML}^{-3}\left(\mathrm{ML}^{-1} \mathrm{~T}^{-2}\right)^{\mathrm{a} 2}(\mathrm{~T})^{\mathrm{b} 2}(\mathrm{M})^{\mathrm{c} 2}
$$

Similarly, equating the basic dimensions to zero:

M: $1+\mathrm{a}_{2}+\mathrm{c}_{2}=0$

L: $-3-\mathrm{a}_{2}=0$

$\mathrm{T}:-2 \mathrm{a}_{2}+\mathrm{b}_{2}=0$

We get,

$\mathrm{a}_{2}=-3, \mathrm{~b}_{2}=-6$ and $\mathrm{c}_{2}=2$

So, Equation (3) can be re-written as;

$$
\pi_{2}=\varrho / \mathrm{F}^{3} \mathrm{t}^{6}
$$

On solving $\pi_{3}$;

$$
\pi_{3}=\mathrm{L}\left(\mathrm{ML}^{-1} \mathrm{~T}^{-2}\right)^{\mathrm{a} 3}(\mathrm{~T})^{\mathrm{b} 3}\left(\mathrm{M}^{\mathrm{c} 3}\right.
$$

Equating the basic dimensions to zero:

$\mathrm{M}: \mathrm{a}_{3}+\mathrm{b}_{3}=0$

L: $1-\mathrm{a}_{3}=0$

$\mathrm{T}:-2 \mathrm{a}_{3}+\mathrm{b}_{3}=0$

We get,

$\mathrm{a}_{3}=1, \mathrm{~b}_{3}=2$ and $\mathrm{c}_{3}=-1$

The Equation (4) for $\pi_{3}$ can be re-written as;

$$
\pi_{3}=1 \mathrm{FT}^{2} / \mathrm{W}
$$

Solving $\pi_{4}$

$$
\pi_{4}=\mathrm{L}^{3}\left(\mathrm{ML}^{-1} \mathrm{~T}^{-2}\right)^{\mathrm{a} 4}(\mathrm{~T})^{\mathrm{b} 4}(\mathrm{M})^{\mathrm{c} 4}
$$

Equating the basic dimensions to zero:

$\mathrm{M}: \mathrm{a}_{4}+\mathrm{c}_{4}=0$

L: $3-\mathrm{a}_{4}=0$

T: $0-2 \mathrm{a}_{4}+\mathrm{b}_{4}=0$

We get,

$\mathrm{a}_{4}=3, \mathrm{~b}_{4}=6$ and $\mathrm{c}_{4}=-3$

The Equation (5) for $\pi_{4}$ can be re-written as;

$$
\pi_{4}=\mathrm{VF}^{3} \mathrm{t}^{6} / \mathrm{W}^{3}
$$

The final relationship between all four Equations of " $\pi$ " can be assumed as; $\pi_{1}=\mathrm{f}\left(\pi_{2}, \pi_{3}\right.$ and $\left.\pi_{4}\right)$ 
Table 1. Modified Taguchi L18 orthogonal array.

\begin{tabular}{|c|c|c|c|c|c|c|c|c|c|}
\hline $\begin{array}{l}\text { Exp. } \\
\text { No. }\end{array}$ & $\begin{array}{c}\text { Tensile } \\
\text { Strength, } \\
\text { N/mm }{ }^{2}\end{array}$ & $\begin{array}{l}\text { Volume of Fused } \\
\text { Deposition Modelling } \\
\text { (FDM) Reinforced } \\
\text { Pattern }\left(\mathrm{mm}^{3}\right)\end{array}$ & $\begin{array}{l}\text { Density of } \\
\text { FDM Pattern, } \\
\mathrm{N} / \mathrm{mm}^{3}\end{array}$ & $\begin{array}{c}\text { BF Cycle } \\
\text { Time (sec) }\end{array}$ & $\begin{array}{c}\text { BF Media } \\
\text { Weight (N) }\end{array}$ & $\begin{array}{l}\text { Mould Wall } \\
\text { Thickness } \\
\text { Obtained, mm }\end{array}$ & $\begin{array}{c}\mathrm{H}, \mathrm{N} / \mathrm{mm}^{2} \\
\text { (Converted from } \mathrm{HV} \\
\text { with a Multiplying } \\
\text { Factor of 9.807) }\end{array}$ & $\begin{array}{c}\Delta \mathrm{d}, \\
\mathrm{mm}\end{array}$ & $\begin{array}{c}\mathbf{R}_{\mathrm{a}}, \mathrm{mm} \text { (Converted from } \\
\mu \mathrm{m} \text { with a Dividing } \\
\text { Factor of } 0.001)\end{array}$ \\
\hline 1 & 21.65 & 17576 & $5.12 \times 10^{-6}$ & 1200 & 98 & 11.5 & 877.72 & 0.026 & 4762 \\
\hline 2 & 21.65 & 17576 & $7.63 \times 10^{-6}$ & 2400 & 147 & 13 & 900.28 & 0.033 & 5151 \\
\hline 3 & 21.65 & 17576 & $9.16 \times 10^{-6}$ & 3600 & 196 & 15 & 1127.80 & 0.02 & 4778 \\
\hline 4 & 21.65 & 27000 & $5.12 \times 10^{-6}$ & 1200 & 147 & 13 & 787.50 & 0.056 & 4371 \\
\hline 5 & 21.65 & 27000 & $7.63 \times 10^{-6}$ & 2400 & 196 & 15 & 848.30 & 0.063 & 5582 \\
\hline 6 & 21.65 & 27000 & $9.16 \times 10^{-6}$ & 3600 & 98 & 11.5 & 1127.80 & 0.053 & 6094 \\
\hline 7 & 21.65 & 39304 & $5.12 \times 10^{-6}$ & 2400 & 98 & 15 & 756.11 & 0.043 & 5368 \\
\hline 8 & 21.65 & 39304 & $7.63 \times 10^{-6}$ & 3600 & 147 & 11.5 & 901.26 & 0.08 & 5658 \\
\hline 9 & 21.65 & 39304 & $9.16 \times 10^{-6}$ & 1200 & 196 & 13 & 984.62 & 0.016 & 6404 \\
\hline 10 & 21.53 & 17576 & $5.12 \times 10^{-6}$ & 3600 & 196 & 13 & 915.97 & 0.016 & 4709 \\
\hline 11 & 21.53 & 17576 & $7.63 \times 10^{-6}$ & 1200 & 98 & 15 & 940.49 & 0.076 & 4573 \\
\hline 12 & 21.53 & 17576 & $9.16 \times 10^{-6}$ & 2400 & 147 & 11.5 & 1317.08 & 0.056 & 4658 \\
\hline 13 & 21.53 & 27000 & $5.12 \times 10^{-6}$ & 2400 & 196 & 11.5 & 934.60 & 0.033 & 5297 \\
\hline 14 & 21.53 & 27000 & $7.63 \times 10^{-6}$ & 3600 & 98 & 13 & 919.89 & 0.05 & 5889 \\
\hline 15 & 21.53 & 27000 & $9.16 \times 10^{-6}$ & 1200 & 147 & 15 & 1024.83 & 0.06 & 6845 \\
\hline 16 & 21.53 & 39304 & $5.12 \times 10^{-6}$ & 3600 & 147 & 15 & 824.76 & 0.033 & 8564 \\
\hline 17 & 21.53 & 39304 & $7.63 \times 10^{-6}$ & 1200 & 196 & 11.5 & 1004.23 & 0.043 & 5721 \\
\hline 18 & 21.53 & 39304 & $9.16 \times 10^{-6}$ & 2400 & 98 & 13 & 1041.50 & 0.046 & 5894 \\
\hline
\end{tabular}


Table 2. Percentage contribution of input process parameters.

\begin{tabular}{cccc}
\hline Source & Surface Hardness $(\mathbf{H})$ & Dimensional Accuracy $(\boldsymbol{\Delta d})$ & Surface Roughness (Ra) \\
\hline $\mathrm{F}_{\mathrm{P}}$ & $7.69 \%$ & $0.76 \%$ & $4.16 \%$ \\
$\mathrm{~V}_{\mathrm{P}}$ & $8.85 \%$ & $16.95 \%$ & $43.84 \%$ * \\
$\mathrm{D}_{\mathrm{P}}$ & $65.75 \% *$ & $19.83 \%$ & $3.03 \%$ \\
$\mathrm{BF}_{\mathrm{T}}$ & $1.03 \%$ & $3.30 \%$ & $6.45 \%$ \\
$\mathrm{BF}_{\mathrm{W}}$ & $0.8 \%$ & $31.71 \% *$ & $2.94 \%$ \\
$\mathrm{~N}_{\mathrm{SL}}$ & $14.14 \%$ & $8.97 \%$ & $5.72 \%$ \\
Residual Error & $1.74 \%$ & $18 \%$ & $33.86 \%$ \\
Total & $100 \%$ & $100 \%$ & $100 \%$ \\
\hline
\end{tabular}

* Highly contributing factor.

Or

$\mathrm{H} / \mathrm{F}=\left(\frac{\rho}{\mathrm{F}^{3} \mathrm{t}^{6}}, \frac{1 \mathrm{Ft}^{2}}{\mathrm{~W}}\right.$ and $\left.\mathrm{VF}^{3} \mathrm{t}^{6} / \mathrm{W}^{3}\right)$

The above expression can be written as:

$$
\mathrm{H}=\mathrm{K} \cdot \varrho \cdot \mathrm{F}^{2} \cdot 1 \cdot \mathrm{t}^{2} \cdot \mathrm{V} / \mathrm{W}^{4}
$$

Here, " $\mathrm{K}$ " is the proportionality constant.

Experimentally, it has been found that a correlation between the hardness and " $\varrho$ " exists (refer Table 2). Hence, it was taken as representative factors to develop the mathematical model. The average values of the hardness obtained at different levels of " $\rho$ " (throughout the Table 1) has been plotted (see details in Figure 4). In this case, a regression equation $\left(R^{2}=1\right)$ with a second order has been determined. Based on the obtained linear equation, the final mathematical model that includes the hardness is given:

$$
\mathrm{H}=\left[\left(2 \mathrm{E}+13 \varrho^{2}-3 \mathrm{E}+8 \varrho+1607.5\right)\right] \mathrm{F}^{2} \cdot \mathrm{L} \cdot \mathrm{t}^{2} \cdot \mathrm{V} / \mathrm{w}^{4}
$$

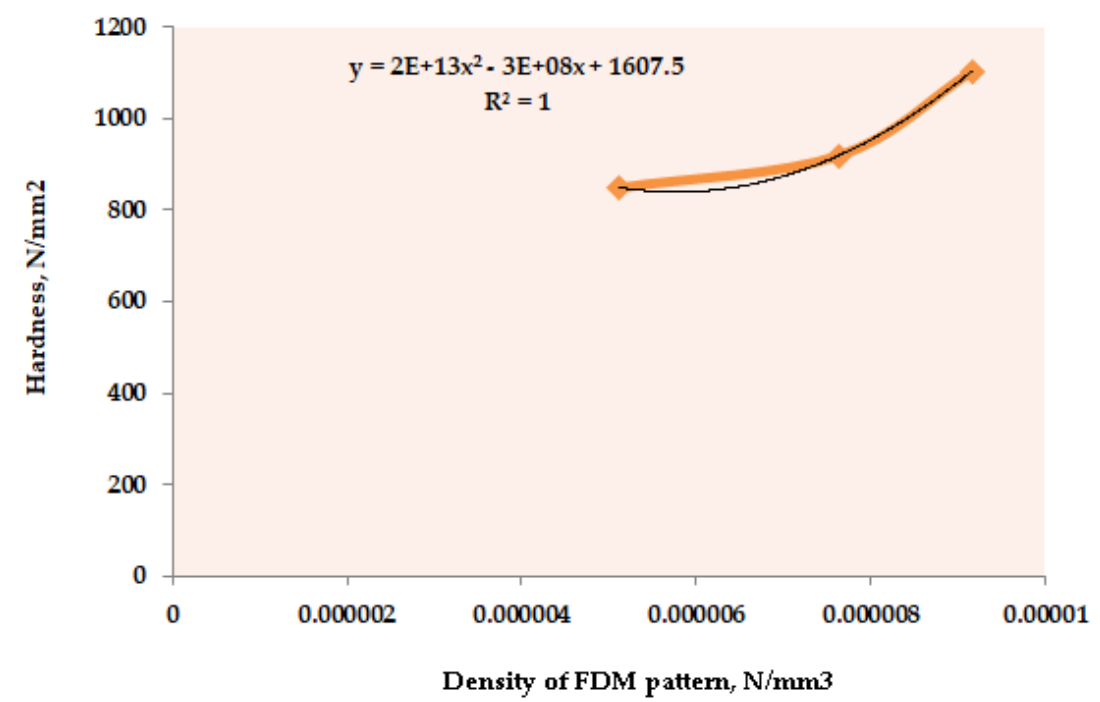

Figure 4. Hardness versus density of fused deposition modelling (FDM) pattern plot.

\subsection{Dimensional Accuracy}

In a similar way, dimensional accuracy is considered as a function of all input process parameters that is expressed by Equation (16).

$$
\Delta \mathrm{d}=f(F, V, \rho, \mathrm{t}, \mathrm{W}, \mathrm{l})
$$


From Table 2, the least significant parameters are BF cycle time, number of IC slurry layers, and filament proportion, that will directly go in " $\pi$ " groups. The " $\pi$ " equation for dimensional accuracy can be written as:

$$
\begin{aligned}
& \pi_{1}=\Delta d(F)^{a 1}(t)^{\mathrm{b} 1}(\mathrm{~L})^{\mathrm{c} 1} \\
& \pi_{2}=\mathrm{W}(\mathrm{F})^{\mathrm{a} 2}(\mathrm{t})^{\mathrm{b} 2}(\mathrm{~L})^{\mathrm{c} 2} \\
& \pi_{3}=\varrho(\mathrm{F})^{\mathrm{a} 3}(\mathrm{t})^{\mathrm{b} 3}(\mathrm{~L})^{\mathrm{c} 3} \\
& \pi_{4}=\mathrm{V}(\mathrm{F})^{\mathrm{a} 4}(\mathrm{t})^{\mathrm{b} 4}(\mathrm{~L})^{\mathrm{c} 4}
\end{aligned}
$$

The same set of mathematical iterations has been repeated for dimensional accuracy and the relationship between the all four " $\pi$ " equations is given in Equation (21) as below:

$$
\Delta \mathrm{d} / \mathrm{l}=f\left(\frac{W}{F t^{2} l^{\prime}}, \frac{\rho \mathrm{l}^{2}}{\mathrm{Ft}^{2}} \text { and } \frac{\mathrm{V}}{\mathrm{l}^{3}}\right)
$$

On solving the above expression, we get:

$$
\Delta \mathrm{d}=\mathrm{K} \cdot \varrho \cdot \mathrm{W} \cdot \mathrm{V} / \mathrm{F}^{2} \cdot 1 \cdot \mathrm{t}^{4}
$$

BF media weight, which is the most significant parameter (refer to Table 2) with regards to dimensional accuracy, of the casted composites, has been taken as the representative parameter to develop the mathematical model. For this, the average values of the dimensional accuracy obtained at different levels of " $\mathrm{BF}_{\mathrm{W}}$ " (throughout the Table 1) has been plotted; refer to Figure 5. Then, a regression equation $\left(R^{2}=1\right)$ with a second order has been determined. Based on the obtained linear equation, the final mathematical model for dimensional accuracy is given as:

$$
\Delta \mathrm{d}=\left[\left(-5 \mathrm{E}-06 \mathrm{~W}^{2}+0.0014 \mathrm{~W}-0.0345\right] \varrho \cdot \mathrm{V} / \mathrm{F}^{2} \cdot 1 \cdot \mathrm{t}^{4}\right.
$$

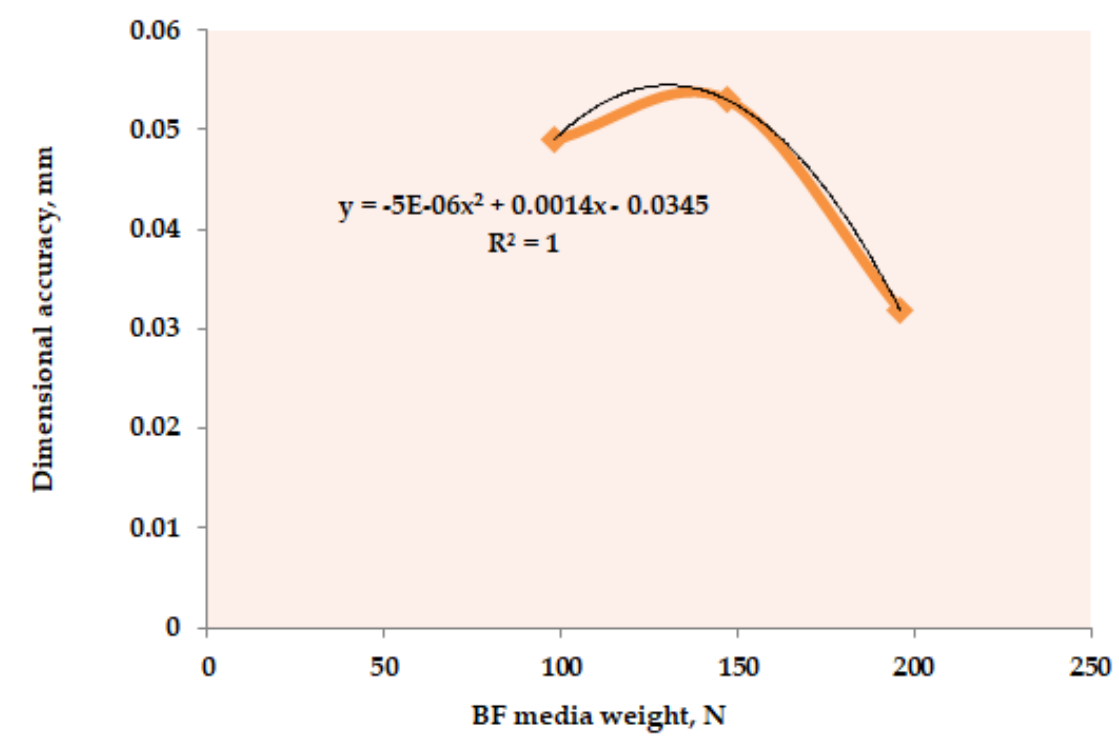

Figure 5. Dimensional accuracy versus barrel finishing (BF) media weight plot.

\subsection{Surface Roughness}

Further, Equation (24) represents the surface roughness, as a function of all input process variable:

$$
\mathrm{Ra}=f(F, V, \rho, \mathrm{t}, \mathrm{W}, \mathrm{l})
$$


Based on the Table 2; density of FDM pattern, filament proportion, and BF media weight are the least significant parameters for surface roughness that will directly go in " $\pi$ " groups. The " $\pi$ " equation for dimensional accuracy can be written as:

$$
\begin{aligned}
\pi_{1} & =\operatorname{Ra}(\mathrm{W})^{\mathrm{a} 1}(\varrho)^{\mathrm{b} 1}(\mathrm{~F})^{\mathrm{c} 1} \\
\pi_{2} & =\mathrm{V}(\mathrm{W})^{\mathrm{a} 2}(\varrho)^{\mathrm{b} 2}(\mathrm{~F})^{\mathrm{c} 2} \\
\pi_{3} & =\mathrm{t}(\mathrm{W})^{\mathrm{a} 3}(\varrho)^{\mathrm{b} 3}(\mathrm{~F})^{\mathrm{c} 3} \\
\pi_{4} & =1(\mathrm{~W})^{\mathrm{a} 4}(\varrho)^{\mathrm{b} 4}(\mathrm{~F})^{\mathrm{c} 4}
\end{aligned}
$$

Now, repeating the same set of mathematical operations the final expression that describes the relationship between all the four " $\pi$ " is given as Equation (29):

$$
\mathrm{R}_{\mathrm{a}}(\rho / \mathrm{W})^{1 / 3}=f\left(\frac{V \rho}{W}, \frac{\mathrm{t}}{(\rho)^{\frac{1}{6}}(\mathrm{FW})^{\frac{1}{3}}} \text { and } 1\left(\frac{\mathrm{W}}{\rho}\right)^{1 / 3}\right)
$$

Equation (29) can be written as:

$$
\mathrm{Ra}=\mathrm{K} \cdot\left(\mathrm{V} \cdot \mathrm{t} \cdot \mathrm{l} \cdot \varrho^{\wedge(1 / 6)}\right) / \mathrm{F}^{1 / 3} \cdot \mathrm{W}^{2 / 3},
$$

Similar to the dimensional accuracy, volume of FDM reinforced pattern which is the most significant parameter (refer to Table 2) with regard to surface roughness, of the casted composites, has been taken as the representative parameter to develop the mathematical model. For this, the average values of the surface roughness obtained at different levels of " $\mathrm{V}_{\mathrm{P}}$ " (throughout Table 1 ) has been plotted; refer to Figure 6 . Then, a regression equation $\left(R^{2}=1\right)$ with a second order has been determined. From the obtained linear equation, the final mathematical model for surface roughness is given as:

$$
R_{a}=\left[\left(-2 E-6 V^{2}+0.2101 \mathrm{~V}+1846.5\right)\right] \cdot\left(t \cdot 1 \cdot \rho^{\frac{1}{6}}\right) / F^{1 / 3} \cdot W^{2 / 3}
$$

These results obtained in the present work are found to be in-line with the observations presented in the literature $[42,45]$.

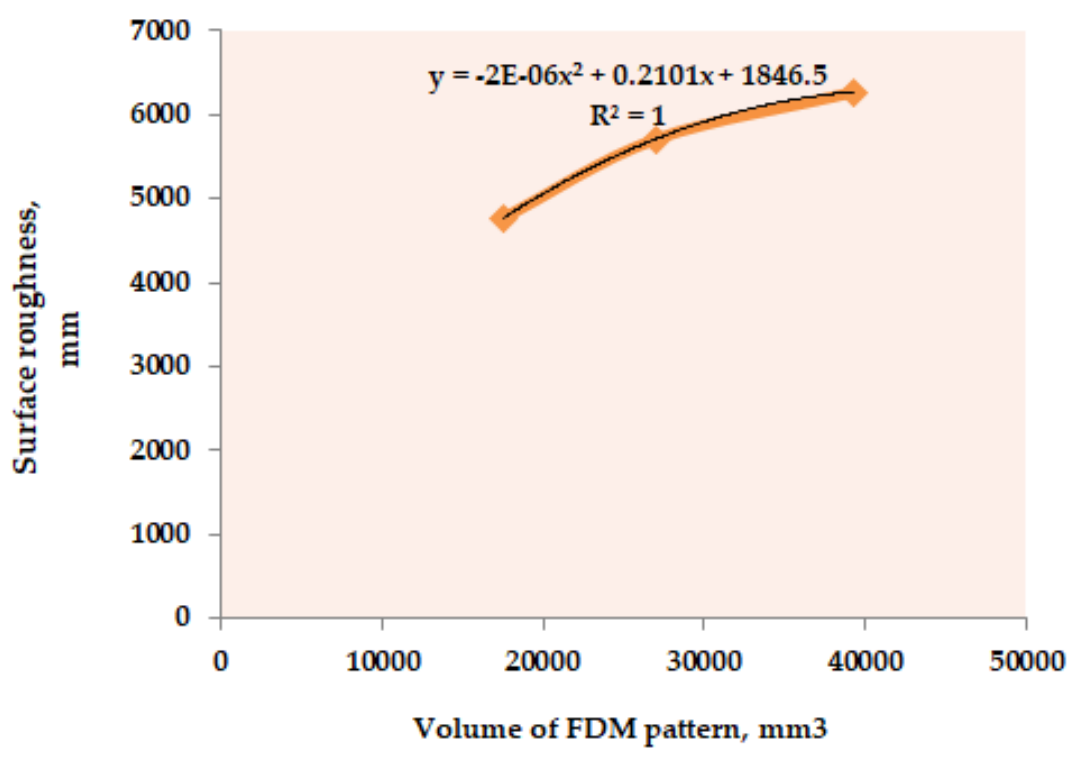

Figure 6. Surface roughness versus volume of FDM pattern plot. 


\section{Conclusions}

In this work, Vashy-Buckingham's $\pi$-theorem was employed successfully for the development of the mathematical models related to the hardness, dimensional accuracy, and surface roughness of AMCs; material that was produced through FDM assisted by the IC process. The ANOVA simulation were embedded in the present methodology in order to generate a standard database and to recognize the significance process parameters, respectively. Further, all three mathematical models developed are of second order polynomial equations, with a regression value equal to 1 , which prove the reliability of the models.

Author Contributions: Conceptualization, S.S. and R.S.; methodology, R.S., S.S; software, S.S., C.P; validation, S.S., P.A., C.P. and C.I.P; formal analysis, S.S., P.A; writing—original draft preparation, S.S., R.S., C.P., C.I.P; writing-review and editing, S.S., C.P., G.K,; supervision, C.P., R.S; project administration, S.S., R.S; funding acquisition, C.P., C.I.P.

Funding: This research received no external funding.

Conflicts of Interest: The authors declare no conflict of interest.

\section{Appendix A}

Table A1. Design of experimentation as per original Taguchi L18 orthogonal array.

\begin{tabular}{|c|c|c|c|c|c|c|c|c|c|c|c|c|}
\hline $\begin{array}{l}\text { Exp. } \\
\text { No. }\end{array}$ & $\mathbf{F}_{\mathbf{P}}$ & $V_{P}\left(\mathrm{~mm}^{3}\right)$ & $\mathbf{D}_{\mathbf{P}}$ & $\mathbf{B F}_{\mathrm{T}}$ & $\mathbf{B F}_{\mathbf{W}}$ & $\mathrm{NS}_{\mathrm{L}}$ & $\begin{array}{c}\mathbf{R}_{\mathrm{a}} \\
(\mu \mathrm{m})\end{array}$ & $\begin{array}{l}\text { S/N ratio } \\
\text { (dB) }\end{array}$ & $\underset{(\mathrm{mm})}{\Delta \mathrm{d}}$ & $\begin{array}{l}\text { S/N ratio } \\
\text { (dB) }\end{array}$ & HV & $\begin{array}{l}\text { S/N ratio } \\
\text { (dB) }\end{array}$ \\
\hline 1 & $\mathrm{C} 1$ & $26 \times 26 \times 26$ & Low density & 20 & 10 & 7 & 4.762 & -13.55 & 0.026 & 31.34 & 89.5 & 39.01 \\
\hline 2 & $\mathrm{C} 1$ & $26 \times 26 \times 26$ & High density & 40 & 15 & 8 & 5.151 & -14.27 & 0.03 & 29.45 & 91.8 & 39.18 \\
\hline 3 & $\mathrm{C} 1$ & $26 \times 26 \times 26$ & Solid & 60 & 20 & 9 & 4.778 & -13.58 & 0.02 & 33.30 & 115 & 41.18 \\
\hline 4 & $\mathrm{C} 1$ & $30 \times 30 \times 30$ & Low density & 20 & 15 & 8 & 4.371 & -12.82 & 0.06 & 23.37 & 80.3 & 38.06 \\
\hline 5 & $\mathrm{C} 1$ & $30 \times 30 \times 30$ & High density & 40 & 20 & 9 & 5.582 & -14.93 & 0.063 & 23.80 & 86.5 & 38.72 \\
\hline 6 & $\mathrm{C} 1$ & $30 \times 30 \times 30$ & Solid & 60 & 10 & 7 & 6.094 & -15.69 & 0.053 & 25.32 & 115 & 41.22 \\
\hline 7 & $\mathrm{C} 1$ & $34 \times 34 \times 34$ & Low density & 40 & 10 & 9 & 5.368 & -14.59 & 0.043 & 27.06 & 77.1 & 37.73 \\
\hline 8 & $\mathrm{C} 1$ & $34 \times 34 \times 34$ & High density & 60 & 15 & 7 & 5.658 & -15.05 & 0.08 & 21.89 & 91.9 & 39.25 \\
\hline 9 & $\mathrm{C} 1$ & $34 \times 34 \times 34$ & Solid & 20 & 20 & 8 & 6.404 & -16.13 & 0.016 & 35.22 & 100.4 & 39.92 \\
\hline 10 & $\mathrm{C} 2$ & $26 \times 26 \times 26$ & Low density & 60 & 20 & 8 & 4.709 & -13.45 & 0.016 & 35.22 & 93.4 & 39.38 \\
\hline 11 & $\mathrm{C} 2$ & $26 \times 26 \times 26$ & High density & 20 & 10 & 9 & 4.573 & -13.20 & 0.076 & 22.29 & 95.9 & 39.62 \\
\hline 12 & $\mathrm{C} 2$ & $26 \times 26 \times 26$ & Solid & 40 & 15 & 7 & 4.658 & -13.36 & 0.056 & 24.72 & 134.3 & 42.60 \\
\hline 13 & $\mathrm{C} 2$ & $30 \times 30 \times 30$ & Low density & 40 & 20 & 7 & 5.297 & -14.48 & 0.033 & 29.45 & 95.3 & 39.56 \\
\hline 14 & $\mathrm{C} 2$ & $30 \times 30 \times 30$ & High density & 60 & 10 & 8 & 5.889 & -15.40 & 0.050 & 25.90 & 93.8 & 39.41 \\
\hline 15 & $\mathrm{C} 2$ & $30 \times 30 \times 30$ & Solid & 20 & 15 & 9 & 6.845 & -16.70 & 0.060 & 24.35 & 104.5 & 40.37 \\
\hline 16 & $\mathrm{C} 2$ & $34 \times 34 \times 34$ & Low density & 60 & 15 & 9 & 8.564 & -18.65 & 0.033 & 29.20 & 84.1 & 38.29 \\
\hline 17 & $\mathrm{C} 2$ & $34 \times 34 \times 34$ & High density & 20 & 20 & 7 & 5.721 & -15.15 & 0.043 & 27.06 & 102.4 & 40.20 \\
\hline 18 & $\mathrm{C} 2$ & $34 \times 34 \times 34$ & Solid & 40 & 10 & 8 & 5.894 & -15.40 & 0.046 & 26.44 & 106.2 & 40.48 \\
\hline
\end{tabular}

Where, $\mathrm{F}_{\mathrm{P}}, \mathrm{V}_{\mathrm{P}}, \mathrm{D}_{\mathrm{P}}, \mathrm{BF}_{\mathrm{T}}, \mathrm{BF}_{\mathrm{W}}, \mathrm{NS}_{\mathrm{L}}, \mathrm{Ra}, \Delta \mathrm{d}, \mathrm{HV}$, and $\mathrm{S} / \mathrm{N}$ represent the filament proportion, volume of the pattern, density of the pattern, barrel finishing time, barrel finishing media weight, number of IC slurry layers, surface roughness, dimensional accuracy/deviation, Vickers hardness, signal/noise, respectively. Further, $\mathrm{C} 1$ and $\mathrm{C} 2$ are the compositions of $\mathrm{PA}_{\mathrm{x}} / \mathrm{Al}_{2} \mathrm{O}_{3 y} / \mathrm{Al}_{\mathrm{z}}$ (where $\mathrm{x}$ is $60 \%$ by wt.; $\mathrm{y}$ is $10 \%$ and $12 \%$ by wt., respectively; and $\mathrm{z:} 28 \%$ and $30 \%$ by wt., respectively).

\section{References}

1. Singh, S.; Singh, R. Investigations for dimensional accuracy of $A M C$ prepared by using $\mathrm{Nylon} 6-\mathrm{Al}_{-}-\mathrm{Al}_{2} \mathrm{O}_{3}$ reinforced FDM filament in investment casting. Rapid Prototyp. J. 2016, 22, 445-455. [CrossRef]

2. Singh, S.; Singh, R. Effect of process parameters on micro hardness of $\mathrm{Al}-\mathrm{Al}_{2} \mathrm{O}_{3}$ composite prepared using an alternative reinforced pattern in fused deposition modelling assisted investment casting. Robot. Comput. Integr. Manuf. 2016, 37, 162-169. [CrossRef]

3. Singh, S.; Singh, R. Some investigations on surface roughness of aluminium metal composite primed by fused deposition modeling-assisted investment casting using reinforced filament. J. Braz. Soc. Mech. Sci. Eng. 2017, 39, 471-479. [CrossRef]

4. Koli, D.K.; Agnihotri, G.; Purohit, R. Advanced aluminium matrix composites: The critical need of automotive and aerospace engineering fields. Mater. Today: Proc. 2015, 2, 3032-3041. [CrossRef] 
5. Iwai, Y.; Honda, T.; Miyajima, T.; Iwasaki, Y.; Surappa, M.K.; Xu, J.F. Dry sliding wear behavior of $\mathrm{Al}_{2} \mathrm{O}_{3}$ fibre reinforced aluminum composites. Compos. Sci. Technol. 2002, 60, 1781-1789. [CrossRef]

6. Barekar, N.; Tzamtzis, S.; Dhindaw, B.K.; Patel, J.; Babu, N.H.; Fan, Z. Processing of aluminum-graphite particulate metal matrix composites by advanced shear technology. J. Mater. Eng. Perform. 2009, 18, 1230-1240. [CrossRef]

7. Kathiresan, M.; Sornakumar, T. Friction and wear studies of die cast aluminum alloy-aluminum oxide-reinforced composites. Ind. Lubr. Tribol. 2010, 62, 361-371. [CrossRef]

8. Miyajima, T.; Iwai, Y. Effects of reinforcement on sliding wear behavior of aluminium matrix composite. Wear 2003, 255, 606-616. [CrossRef]

9. Prasad, S.V.; Asthana, R. Aluminum metal-matrix composites for automotive applications: Tribological considerations. Tribol. Lett. 2004, 17, 445-453. [CrossRef]

10. Surappa, M.K. Aluminium matrix composites challenges and opportunities. Sadhana 2003, 28, 319-325. [CrossRef]

11. Mohan, S.; Srivastava, S. Surface behaviour of as Cast Al-Fe intermetallic composites. Tribol. Lett. 2006, 22, 45-51. [CrossRef]

12. Sajjadi, S.A.; Ezatpour, H.R.; Parizi, M.T. Comparison of microstructure and mechanical properties of A356 aluminum alloy $/ \mathrm{Al}_{2} \mathrm{O}_{3}$ composites fabricated by stir and compo-casting processes. Mater. Des. 2012, 34, 106-111. [CrossRef]

13. Ralph, B.; Yuen, H.C.; Lee, W.B. The processing of metal matrix composites-An overview. J. Mater. Process. Technol. 1997, 63, 339-353. [CrossRef]

14. Kurşun, A.; Bayraktar, E.; Robert, M.H. Low cost manufacturing of aluminium-alumina composites. Adv. Mater. Process. Technol. 2015, 1, 515-528. [CrossRef]

15. Woo, K.D.; Huo, H.W. Effect of high energy ball milling on displacement reaction and sintering of $\mathrm{Al}-\mathrm{Mg} / \mathrm{SiO} 2$ composite powders. Met. Mater. Int. 2006, 12, 45. [CrossRef]

16. Tjong, S.C.; Ma, Z.Y. Microstructural and mechanical characteristics of in situ metal matrix composites. Mater. Sci. Eng. R Rep. 2000, 29, 49-113. [CrossRef]

17. Maleki, A.; Niroumand, B.; Meratian, M. Effects of processing temperature on in-situ reinforcement formation in $\mathrm{Al}(\mathrm{Zn}) / \mathrm{Al}_{2} \mathrm{O}_{3}(\mathrm{ZnO})$ nanocomposite. Metall. Mater. Eng. 2015, 21, 283-291. [CrossRef]

18. Afkham, Y.; Khosroshahi, R.A.; Rahimpour, S.; Aavani, C.; Brabazon, D.; Mousavian, R.T. Enhanced mechanical properties of in situ aluminium matrix composites reinforced by alumina nanoparticles. Arch. Civ. Mech. Eng. 2018, 18, 215-226. [CrossRef]

19. Harrigan, W.C. Commercial processing of metal matrix composites. Mater. Sci. Eng. A 1998, 244, 75-79. [CrossRef]

20. Degischer, H.P. Innovative light metals: Metal matrix composites and foamed aluminium. Mater. Des. 1997, 18, 221-226. [CrossRef]

21. Neussl, E.; Sahm, P.R. Selectively reinforced component produced by the modified investment casting process. Compos. Part A 2001, 32, 1177-1183. [CrossRef]

22. Mazahery, A.; Abdizadeh, H.; Baharvandi, R. Development of high-performance $\mathrm{A} 356 / \mathrm{nano}-\mathrm{Al}_{2} \mathrm{O}_{3}$ composites. Mater. Sci. Eng. A 2009, 518, 61-64. [CrossRef]

23. Singh, S.; Singh, R. Fused deposition modelling based rapid patterns for investment casting applications: A review. Rapid Prototyp. J. 2016, 22, 123-143. [CrossRef]

24. Kumar, P.; Ahuja, I.S.; Singh, R. Experimental investigations on hardness of the biomedical implants prepared by hybrid investment casting. J. Manuf. Process. 2016, 21, 160-171. [CrossRef]

25. Kisasoz, A.; Guler, K.A.; Karaaslan, A. Infiltration of A6063 aluminium alloy into SiC $-\mathrm{B}_{4} \mathrm{C}$ hybrid preforms using vacuum assisted block mould investment casting technique. Trans. Nonferrous Met. Soc. China 2012, 22, 563-1567. [CrossRef]

26. Reddy, C.; Zitoun, E. Tensile behavior of $6063 / \mathrm{Al}_{2} \mathrm{O}_{3}$ particulate metal matrix composites fabricated by investment casting process. Int. J. Appl. Eng. Res. 2010, 1, 542-552.

27. Rooks, B. Rapid tooling for casting prototypes. Assem. Autom. 2012, 22, 40-45. [CrossRef]

28. Kakde, K.U.; Tumane, A.S. Development of customized innovative product using fused deposition modeling technique of rapid prototyping and investment casting. In Proceedings of the National Conference on Innovative Paradigms in Engineering and Technology, Nagpur, Maharashtra, India, 28 January 2012; pp. 27-30. 
29. Singh, R.; Singh, S.; Mahajan, V. Investigations for dimensional accuracy of investment casting process after cycle time reduction by advancements in shell moulding. Procedia Mater. Sci. 2014, 6, 859-865. [CrossRef]

30. Singh, R.; Singh, S.; Singh, G. Dimensional accuracy comparison of investment castings prepared with wax and abs patterns for bio-medical application. Procedia Mater. Sci. 2014, 6, 851-858. [CrossRef]

31. Boschetto, V.G.; Veniali, F. Modelling micro geometrical profiles in fused deposition process. Int. J. Adv. Manuf. Technol. 2012, 61, 945-956. [CrossRef]

32. Blake, P.; Fodran, E.; Koch, M.; Menon, U.; Priedeman, B.; Sharp, S. FDM of ABS patterns for investment casting. In Proceedings of the 1997 International Solid Freeform Fabrication Symposium, Austin, TX, USA, 11-13 August 1997.

33. Hafsa, M.N.; Ibrahim, M.; Wahab, M.; Zahid, M.S. Evaluation of FDM pattern with ABS and PLA material. In Applied Mechanics and Materials; Trans Tech Publications: Switzerland, Switzerland, 2014; Volume 465, pp. 55-59.

34. Harun, W.S.; Sharif, S.; Idris, M.H.; Kadirgama, K. Characteristic studies of collapsibility of ABS patterns produced from FDM for investment casting. Mater. Res. Innov. 2009, 13, 340-343. [CrossRef]

35. Harun, W.S.; Safian, S.; Idris, M.H. Evaluation of ABS patterns produced from FDM for investment casting process. Comput. Method Exp. Mater. Characterisation IV 2009, 1, 319-328.

36. Idris, M.H.; Sharif, S.; Harun, W.S. Evaluation of ABS patterns produced from FDM for investment casting process. In Proceedings of the 9th Asia Pasific Industrial Engineering \& Management Systems Conference, Kaohsiung, Taiwan, 3-5 December 2008; pp. 3-5.

37. Singh, S.; Singh, R. Study on tribological properties of $\mathrm{Al}-\mathrm{Al}_{2} \mathrm{O}_{3}$ composites prepared through FDMAIC route using reinforced sacrificial patterns. J. Manuf. Sci. Eng. 2016, 138, 021009. [CrossRef]

38. Singh, R.; Singh, S. Effect of process parameters on surface hardness, dimensional accuracy and surface roughness of investment cast components. J. Mech. Sci. Technol. 2013, 27, 191-197. [CrossRef]

39. Sun, S.C.; Bo, Y.; Liu, M.P. Effects of moulding sands and wall thickness on microstructure and mechanical properties of Sr-modified A356 aluminum casting alloy. Trans. Nonferrous Met. Soc. China 2012, 22, 1884-1890. [CrossRef]

40. Jiang, W.; Fan, Z.; Chen, X.; Wang, B.; Wu, H. Combined effects of mechanical vibration and wall thickness on microstructure and mechanical properties of A356 aluminum alloy produced by expendable pattern shell casting. Mater. Sci. Eng. A 2014, 619, 228-237. [CrossRef]

41. Bikas, H.; Stavropoulos, P.; Chryssolouris, G. Additive manufacturing methods and modelling approaches: A critical review. Int. J. Adv. Manuf. Technol. 2015, 83, 389-405. [CrossRef]

42. Shanmughasundaram, P. Investigation on the Wear Behaviour of Eutectic Al-Si Alloy- $\mathrm{Al}_{2} \mathrm{O}_{3}-\mathrm{Graphite}$ Composites Fabricated Through Squeeze Casting. Mater. Res. 2014, 17, 940-946. [CrossRef]

43. Singh, S.; Singh, R. Wear modelling of $\mathrm{Al}-\mathrm{Al}_{2} \mathrm{O}_{3}$ functionally graded material prepared by FDM assisted investment castings using dimensionless analysis. J. Manuf. Process. 2015, 20, 507-514. [CrossRef]

44. Wang, J. Predictive depth of jet penetration models for abrasive water jet cutting of alumina ceramics. Int. J. Mech. Sci. 2007, 49, 306-316. [CrossRef]

45. Anders, D.; Munker, T.; Artel, J.; Weinberg, K. A dimensional analysis of front-end bending in plate rolling applications. J. Mater. Process. Technol. 2012, 212, 1387-1398. [CrossRef]

46. Singh, R.; Khamba, J.S. Mathematical modeling of surface roughness in ultrasonic machining of titanium using Buckingham-П approach: A Review. Int. J. Abras. Technol. 2009, 2, 3-24. [CrossRef]

47. Tinker, D.C.; Osborne, R.J.; Pitz, R.W. Annular-Electrode Spark Discharges in Flowing Oxygen: Buckingham Pi Analysis; American Inst. of Aeronautics and Astronautics: Reston, VA, USA, 2019.

48. Ekici, C.; Teke, I. Developing a new solar radiation estimation model based on Buckingham theorem. Results Phys. 2018, 9, 263-269. [CrossRef]

49. Tavakoli, S.; Sadeghi, J.; Griffin, I.; Fleming, P.J. PI controller tuning for load disturbance rejection using constrained optimization. Int. J. Dyn. Control 2018, 6, 188-199. [CrossRef]

50. Salmani, F.; Mahpeykar, M.R.; Rad, E.A. Estimating heat release due to a phase change of high-pressure condensing steam using the Buckingham Pi theorem. Eur. Phys. J. Plus 2019, 134, 48. [CrossRef]

51. Bakhtar, F.; White, A.J.; Mashmoushy, H. Theoretical treatments of two-dimensional two-phase flows of steam and comparison with cascade measurements. Proc. Inst. Mech. Eng. Part C J. Mech. Eng. Sci. 2005, 219, 1335-1355. [CrossRef] 
52. Buckingham, E. On physically similar systems; illustrations of the use of dimensional equations. Phys. Rev. 1914, 4, 345. [CrossRef]

53. Zohuri, B. Dimensional Analysis beyond the Pi Theorem; Springer: Berlin, Germany, 2017.

(c)

(C) 2019 by the authors. Licensee MDPI, Basel, Switzerland. This article is an open access article distributed under the terms and conditions of the Creative Commons Attribution (CC BY) license (http://creativecommons.org/licenses/by/4.0/). 